\title{
Comparison of efficacy rinsing with cocoa seed extract, green tea catechins extract and lime extract to salivary ph in children suffering ECC (Early Childhood Caries)
}

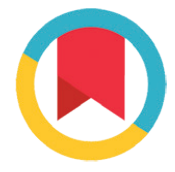

CrossMark

\author{
Fajriani*, Meilisa Yusriyanti
}

\section{Abstract}

Objective: This study aims to determine whether $12.5 \%$ cocoa extract, green tea catechins 30\% extract, or $40 \%$ lime extract are effective in changing saliva $\mathrm{pH}$ to become more alkaline and prevent against dental caries.

Material and Methods: This study used purposive sampling with pretest/post-test control group design. The total sample group included 120 children who fulfilled the criteria. The control group, containing 30 children, was rinsed with distilled water while 90 children were divided into 3 intervention groups containing 30 children each. Each intervention group was treated with either a solution of $12.5 \%$ cocoa seed extract, a solution of $30 \%$ green tea catechins extract or a solution of $40 \%$ lime extract.

Results: Using the Friedman Test, rinsing with distilled had no significant effect in changing the $\mathrm{pH}$ of saliva into normal alkaline conditions and preventing against dental caries. Significant changes the $\mathrm{pH}$ of saliva was found with $12.5 \%$ cocoa seed extract after the first 15 minutes resulting in alkaline or normal conditions for prevention of dental caries.

Conclusion: The mouthwash solution containing 12.5\% cocoa seed extract is most effective to change the $\mathrm{pH}$ of the saliva into alkaline and normal state in preventing dental caries.
Department of Pediatrics, Faculty of Dentistry, Hasanuddin University, Makassar, Indonesia
*Corresponding to: Fajriani, Department of Pediatrics, Faculty of Dentistry, Hasanuddin University, Makassar, Indonesia fajrianifkg@gmail.com

Received: 22 0ctober 2017 Revised: 6 November 2017 Accepted: 14 January 2018 Available online: 1 April 2018

Keywords: Polyphenols, Green tea extract, Catechins, Essential oils

Cite this Article: Fajriani, Yusriyanti M. 2018. Comparison of efficacy rinsing with cocoa seed extract, green tea catechins extract, and lime extract to salivary ph in children suffering ECC (Early Childhood Caries). Journal of Dentomaxillofacial Science 3(1): 20-23. D0I: 10.15562/jdmfs.v3i1.633

\section{Introduction}

The prevalence of caries in patients remains high, especially in children. In 1995, The National Oral Health School Survey reported that $87.1 \%$ of children aged 5 years old had some degree of tooth caries. Again in 2005, National Oral Health reported that $76.2 \%$ of children aged 5 years old had some degree of tooth caries. ${ }^{1}$ According to the American Academy of Pediatric Dentistry (AAPD), early childhood caries (ECC) is the presence of one or more damaged, missing or filled primary teeth in children aged 71 months or younger.

Caries is a disease in the hard tissue of teeth characterized by demineralization of dental hard tissue that occurs as a result of bacterial invasion and death of the pulp. The spread of the infection to the periapical tissue can cause pain. ${ }^{2}$ As proposed in the theory of caries, there are three factors that influence the occurrence of caries; teeth and saliva, microorganisms, and substrates or food. ${ }^{3}$ The process of tooth decay occurs over time and is caused by the interaction between acid-producing bacteria and fermentable carbohydrates. Other host factors include teeth and saliva and in this case, saliva is a major factor that triggers caries. ${ }^{2,4}$

Teeth are always covered by saliva and the susceptibility to dental caries depends a lot on the saliva environment. Saliva covers or envelops the entire surface of the tissue inside the mouth and about 90 percent of saliva is produced during mastication. The role of saliva is not only for the mastication process but also to protect the tissue inside the oral cavity. ${ }^{5,6}$ In normal circumstances, salivary $\mathrm{pH}$ is about 6.8 to 7.2 but some types of carbohydrates are converted by bacteria and result in a decreased $\mathrm{pH}$ of the saliva. ${ }^{7}$ Natural ingredients from plants in Indonesia can be used to inhibit this process. For example, cocoa beans contain many active components, one of which is polyphenol. Polyphenols contained in cocoa beans can inhibit the growth of Streptococcus mutans that are the main bacteria responsible for the cause of caries. As a natural product that exists in Indonesia, cocoa beans have antibacterial properties demonstrated in research by Purnamasari et al. ${ }^{8}$ The effective concentration of cocoa seed extract which could inhibit the growth of Streptococcus mutans was found to be $12.5 \%$.

Another natural product explored is green tea. The benefits of green tea for health are attributed to the polyphenols contained in the tea. The main polyphenols are the catechins group: epicatechin (EC), epigallocatechin (EGC), epicatechin gallate (ECG), epigallocatechin gallate (EGCG), epigallate 
(EG) and catechin (C). Polyphenols are not only beneficial to health but they also have antimicrobial and antiviral properties. Tea polyphenols are also active in inhibiting the growth of streptococcus mutans and excellent in reducing the formation of streptococcus mutans. Approximately 25 to $30 \%$ of catechins have antibacterial effects such as anti-caries and inhibiting halitosis. ${ }^{9}$ That green tea leaf extract suppresses the growth of streptococcus mutans. The combination of green tea compounds is bactericidal against streptococcus mutans. ${ }^{10}$

Citrus aurantifolia, also known as lime, is a plant belonging to the family Rutaceae. Extracts of lime are now widely used in daily life. Lime contains compounds, such as citric acid, amino acids (tryptophan and lysine), essential oils (limonene, lanolin acetate, geranyl acetate, phellandrene, Citral, chamfer lemon, cadinen, acetaldehyde, and aldehyde) and vitamin $A, B 1$ and $C$, that have a variety of benefits. Studies show that the citric acid extracts have very high antimicrobial activity. Research conducted by Fajriani, et al. shows that lime extract, with a concentration of $40 \%$, can inhibit bacterial growth.

\section{Material and Methods}

This study uses $12.5 \%$ extracts of cocoa seed, $30 \%$ catechin extract and $40 \%$ lime extract. Cocoa seed extract was made at the Laboratory of Phytochemistry Faculty of Pharmacy, University of Hasanuddin. In this research, the researcher using purposive sampling method with pre-test/post-test control group design. Total sample group was 120 children who met the criteria. The control group, containing 30 children, was rinsed with distilled water while 90 children were divided into 3 intervention groups containing 30 children each. Each intervention group was treated with either a solution of $12.5 \%$ cocoa seed extract, a solution of $30 \%$ green tea catechins extract or a solution of $40 \%$ lime extract. Each sample was given the same intervention. First, saliva was taken before intervention (pre-test). Each group was then asked to rinse with a solution of $12.5 \%$ cocoa seed extract, $30 \%$ green tea catechins extract, or $40 \%$ lime extract. Each child rinsed with $10 \mathrm{~mL}$ of the specified solution for 30 seconds. Saliva was taken twice after rinsing, at 15 minutes (post-test 1 ) and 30 minutes (post-test 2). The saliva was examined by looking at changes in the salivary $\mathrm{pH}$ by using a Universal $\mathrm{pH}$ meter test. Processing and data analysis was performed using SPSS version 22.0 for Windows.

\section{Results}

Observations on changes in the $\mathrm{pH}$ of saliva after rinsing with $12.5 \%$ cocoa seed extract solution, $30 \%$ green tea catechins extract solution, $40 \%$ lime extract solution and distilled water.

Table 1 and figure 1 show the mean salivary $\mathrm{pH}$ before and after rinsing with distilled water as a mouthwash. Before the intervention, the salivary $\mathrm{pH}$ was 6.80 . After 15 minutes (post-test 1 ) the $\mathrm{pH}$ increased to 6.83 and after 30 minutes (post-test 2) the $\mathrm{pH}$ remained the same at 6.83 . This means that distilled water solution has no significant effect in changing the $\mathrm{pH}$ of saliva into a normal alkaline condition or in prevention against dental caries. Table 2 and figure 2 show

Table 1 Differences in mean of salivary $\mathrm{pH}$ in each time interval in sample rinsing with distilled water

\begin{tabular}{|c|c|c|c|c|}
\hline \multirow{2}{*}{ Solution } & Pre & Post 1 & Post 2 & \\
\hline & Mean \pm SD & Mean \pm SD & Mean \pm SD & P-value \\
\hline Distilled water & $6.80 \pm 0.407$ & $6.83 \pm 0.379$ & $6.83 \pm 0.379$ & $0.368^{*}$ \\
\hline
\end{tabular}

${ }^{*}$ Friedman Test: $\mathrm{p}>0.05$ : not significant

Table 2 Differences in mean of salivary pH in each time interval in sample rinsing with $12.5 \%$ cacao seed

\begin{tabular}{|c|c|c|c|c|}
\hline \multirow{2}{*}{ extract } & Pre & Post 1 & Post 2 & \\
\hline & Mean \pm SD & Mean \pm SD & Mean \pm SD & P-value \\
\hline Cacao seed extract & $6.23 \pm 0.728$ & $6.80 \pm 0.925$ & $6.87 \pm 0.346$ & $0.000^{*}$ \\
\hline
\end{tabular}

${ }^{*}$ Friedman Test: $\mathrm{p}<0.05$ : significant

Table 3 Differences in mean of salivary $\mathrm{pH}$ in each time interval in sample rinsing with $30 \%$ green tea catechins extract

\begin{tabular}{|c|c|c|c|c|}
\hline \multirow{2}{*}{ Solution } & Pre & Post 1 & Post 2 & \multirow[b]{2}{*}{ P-value } \\
\hline & Mean \pm SD & Mean \pm SD & Mean \pm SD & \\
\hline green tea catechins extract & $6.47 \pm 0.507$ & $6.03 \pm 0.615$ & $6.77 \pm 0.430$ & $0.000^{*}$ \\
\hline
\end{tabular}

${ }^{\star}$ Friedman Test: $\mathrm{p}<0.05$ : significant 
Table 4 Difference in mean of salivary $\mathrm{pH}$ in each time interval in sample rinsing with $40 \%$ lime

\begin{tabular}{|c|c|c|c|c|}
\hline \multirow[t]{2}{*}{ extract } & Pre & Post 1 & Post 2 & P-value \\
\hline & Mean \pm SD & Mean \pm SD & Mean \pm SD & Mean \pm SD \\
\hline Lime extract & $6.50 \pm 0.509$ & $5.13 \pm 0.629$ & $6.87 \pm 0.507$ & $0.000^{*}$ \\
\hline
\end{tabular}

${ }^{*}$ Friedman Test: $\mathrm{p}<0.05$ : significant

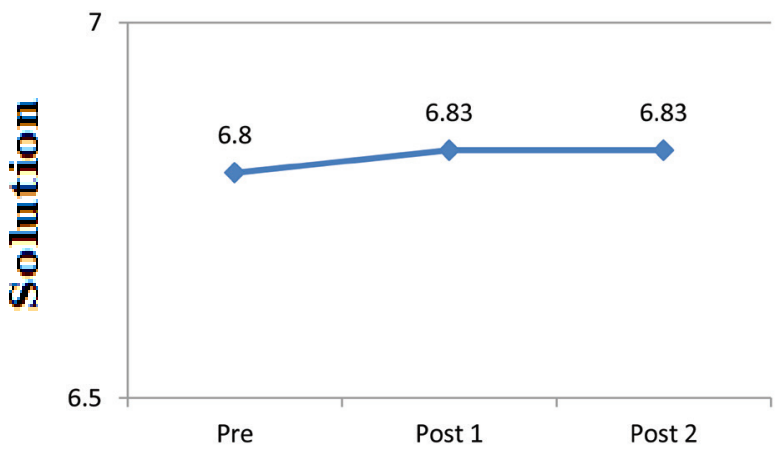

Figure 1 Distilled water

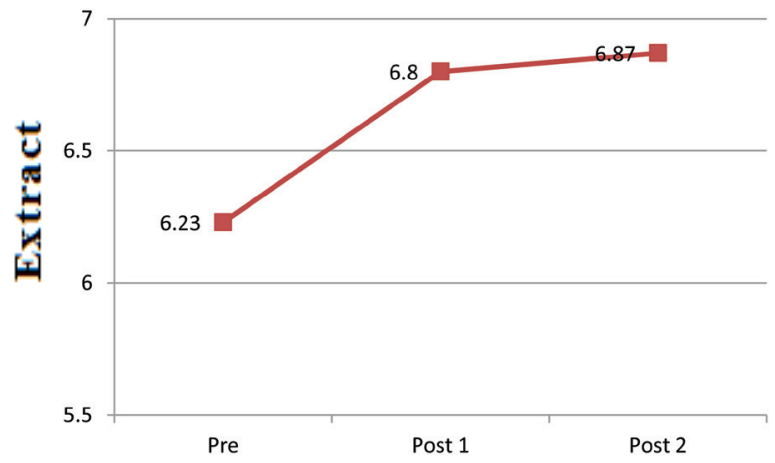

Figure 2 Cacao seed extract

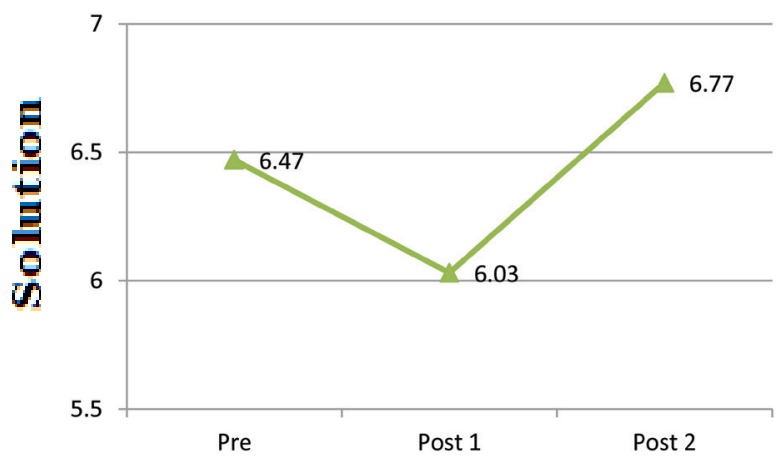

Figure 3 Green tea catechin extract

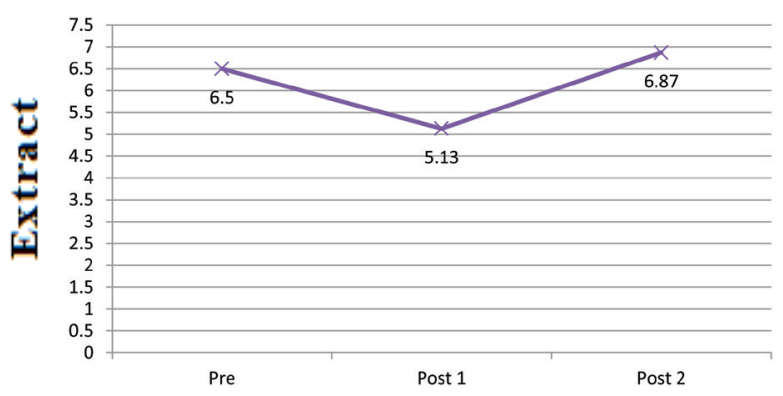

Figure 4 Lime extract the mean salivary $\mathrm{pH}$ before and after rinsing with $12.5 \%$ cocoa seed extract solution. Before rinsing, the salivary $\mathrm{pH}$ was 6.23 , after post-test 1 the $\mathrm{pH}$ increased to 6.80 , and after post-test 2 it increased to 6.87 . This means $12.5 \%$ cocoa seed extract solution had a significant influence in changing the $\mathrm{pH}$ of saliva into a normal alkaline condition or in prevention against dental caries. Table 3 and figure 3 show the mean salivary $\mathrm{pH}$ before and after rinsing with $30 \%$ green tea catechins extract solution. The $\mathrm{pH}$ of the saliva before rinsing was 6.47, after post-test 1 the $\mathrm{pH}$ decreased to 6.03, and after post-test 2 it increased to 6.77 . This shows that $30 \%$ catechins green tea extract solution has a significant influence on changing the $\mathrm{pH}$ of saliva to become more acidic and alkaline. Table 4 and figure 4 shows the mean salivary $\mathrm{pH}$ before and after rinsing with $40 \%$ lime extract solution. The $\mathrm{pH}$ of saliva before rinsing was

6.50, after post-test 1 the $\mathrm{pH}$ decreased to 5.13, and after post-test 2 the $\mathrm{pH}$ increased to 6.87 . This means that $40 \%$ lime extract solution has a significant influence in changing the $\mathrm{pH}$ of saliva to become acidic and alkaline.

\section{Discussion}

In the study conducted by Purnamasari et al., the concentration of cocoa seed extracts required to inhibit the growth of Streptococcus mutans is most effective at $12.5 \%$. In research by Fajriani et al., it is shown that a concentration of $40 \%$ lime extract can reduce the number of Streptococcus mutans colonies. In research by Palwankar, it is mention that $25-35 \%$ of catechins in green tea leaves have antibacterial and anti-caries properties. ${ }^{8,9,11}$

The data obtained showed there is a change in $\mathrm{pH}$ of the saliva before and after the intervention given to the samples (Pre-test/Post-test 1/Posttest 2). There was no significant changes in the $\mathrm{pH}$ of saliva after rinsing with distilled water. Rinsing with $12.5 \%$ cocoa seed extract resulted in a change in the $\mathrm{pH}$ of saliva. There was an increase in the $\mathrm{pH}$ of saliva after each time interval. This means that $12.5 \%$ cocoa seed extract solution had a significant influence in changing the $\mathrm{pH}$ of saliva into normal or alkaline conditions that can help prevent against dental caries. After rinsing with 30\% catechin green tea extract, we can see a decrease of salivary 
$\mathrm{pH}$ at after post-test 1 but then there is an increase in salivary $\mathrm{pH}$ after post-test 2 . This means $30 \%$ catechins green tea extract solution has a significant influence in changing the $\mathrm{pH}$ of saliva into the acidic, normal, and alkaline conditions. Rinsing with $40 \%$ lime extract show a significant reduction of salivary $\mathrm{pH}$ after post-test 1 and but there was an increase in $\mathrm{pH}$ after post-test 2 . This means that $40 \%$ lime extract solution has a significant influence in changing the $\mathrm{pH}$ of saliva to become acidic, alkaline and normal.

From these results it can be concluded that rinsing with a solution of $12.5 \%$ cacao seed extract and $30 \%$ green tea catechins extract can increase the salivary $\mathrm{pH}$. However, the cocoa seed extract solution most effectively raises the $\mathrm{pH}$ of saliva after each time interval.

\section{Conclusion}

Based on the analysis results, rinsing with $12.5 \%$ cocoa seed extract is most effective in changing the $\mathrm{pH}$ of the saliva to become more alkaline or normal and therefore, prevents against dental caries.

\section{Acknowledgment}

Laboratory of Phytochemistry Faculty of Pharmacy, University of Hasanuddin for providing facilities required for the successful completion of the research work.

\section{Conflict of Interest}

The author report no conflict of interest.

\section{References}

1. Zahara AM, Nur Ili MT, Yahya NA. Dietary habits and dental caries occurrence among young children: does the relationship still exist. Malay J Med \& Health Sci 2013;9: 9-20.

2. Kidd EAM, Joyston-Bechal S. Dasar-dasar karies penyakit dan penanggulanannya. Jakarta: EGC; 1991. p. 1-2, 8.

3. Grewal H, Verma M, Kumar A. Prevalence of dental caries and treatment needs in the rural child population of Nainital District, Uttaranchal. J Indian Soc Pedod Prev Dent 2009;27: 224-226.

4. Widowati W, Akbar SH, Tin MH. Saliva $\mathrm{pH}$ changes in patients with high and low caries risk after consuming organic (sucrose) and non-organic (maltitol) sugar. Int Med J Malay 2013;12: 15-21.

5. Illahi G, Tamril R, Samad R. Concentration of total protein and degree of acidity $(\mathrm{pH})$ of saliva when fasting and after breakfasting. J Dentomaxillofac Sci 2016;1: 36-38

6. Selviani Y, Mas'ud N, Fitri A, et al. Inorganic component of saliva during fasting and after fast break. J Dentomaxillofac Sci 2016;1: 125-128

7. Sambow SC, Abidjulu J, Gunawan P. Gambaran pH saliva anak-anak madrasah ibtidaiyah darul istiqamah bailing. PAAI 2014;2: 1-7.

8. Purnamasari DA, Munadzhiroh E, Yogiartono RM. Konsentrasi ekstrak biji kakao sebagai material alam dalam menghambat pertumbuhan streptococcus mutans. Jurnal PDGI 2010;59: 14-15, 17.

9. Palwankar P, Gopal L, Verma A. Green tea a magical herbal therapy. Int J Oral Health Dentistry 2015;1: 16-19.

10. Carmen C, Reyes A, Rafael G. Beneficial effects of green tea-a review. 2006;25: 79-99.

11. Fajriani, Mahrum. Effectiveness of lime (citrus aurantifolia) extract solution inhibiting bacteria Streptococcus mutans case of early childhood caries. DJDOH 2015;1: 17.

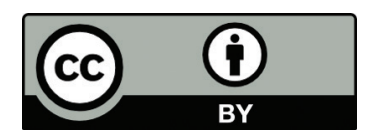

This work is licensed under a Creative Commons Attribution 